\title{
Investigation of the Relationship Between Adolescents' Career Indecision, and Social Support Perception and Basic Psychological Needs
}

\author{
Umay Bilge Baltac ${ }^{1}$, Kemal Öztemel ${ }^{2} \&$ Zeliha Tras $^{1}$ \\ ${ }^{1}$ Education Faculty, Necmettin Erbakan University, Konya, Turkey \\ ${ }^{2}$ Gazi Education Faculty, Gazi University, Ankara, Turkey \\ Correspondence: Zeliha Tras, Education Faculty, Necmettin Erbakan University, Konya, Meram Yeniyol 42090, \\ Turkey. E-mail: zztras@gmail.com
}

Received: April 15, 2020

doi:10.5539/ies.v13n10p113
Accepted: May 21, $2020 \quad$ Online Published: September 25, 2020

URL: https://doi.org/10.5539/ies.v13n10p113

\begin{abstract}
The aim of this study is to examine the relationship between high school students' emotional and personality-related career decision-making difficulties (EPCD), perception of social support and basic psychological needs. The predictive effect of social support perception and basic psychological needs on EPCD will also be examined. In addition, it has been examined whether emotional and personality-related career decision-making difficulties differ according to some demographic variables. In this research, survey model was used. For collecting data, Personal information form; the EPCD-short form; New Psychological Needs Assessment Scale, were used. The data obtained in this research were analyzed using SPSS (20). In the analysis of the data, descriptive statistics, independent groups t-test, ANOVA test, and correlation and regression analysis technique were used. In addition, a significant correlation was found between the mean scores of the students on the career difficulties, and the perceived social support, and the autonomy and the achievement. The findings were discussed as a part of the relevant literature and suggestions based on the findings were included.
\end{abstract}

Keywords: career indecision, social support, basic psychological needs, adolescents

\section{Introduction}

Career can be specified as the work that the individual performs throughout her/his life, the specific events that enable achievements to occur, and a general way of determining the roles and responsibilities of the individual (Kuzgun, 2009). Career development can be seen as a process that begins in childhood, continues in adulthood through the advancement of a person's career behavior, and covers most of the life span (Lent \& Brown, 2013). Career is an integral part of other aspects of personal identity. The career choice of adolescents and young adult individuals is thought to be related to two main life goals. First, it provides economic independence. Second, establishing a lifestyle consistent with personal opinions about family life and child rearing is also dependent on a person's career (Davidson \& Gilbert, 1993).

Career decision-making is a process in which people determine their future through a developmental course (Kirdök, 2018). Career choices are among the most important decisions people make throughout their lives (Gati $\&$ Tal, 2018). Such decisions generally have life-long consequences for the individual's professional future and psychological well-being (Obiunu, 2008). Some individuals make such decisions easily. On the contrary some individuals face difficulties in decisions making, and many of them need professional help. There are several goals of career counseling. One of the main goals of career counseling is to facilitate the decision making of the client and especially to help them overcome the difficulties they face in career process (Gaff, Krausz, \& Osipow, 1996). It is believed that determining the differences and similarities between the behaviors, experiences and emotions of the people who have problems in the decision-making process will contribute to the better understanding of the decision-making process of these individuals (Bacanl, 2000). It can be thought that adolescents' gaining ability to manage decision-making processes will increase their awareness of their abilities, needs and motivations (Gökçe \& Traş, 2017).

Although there are various approaches to understanding career difficulties, Saka, Gati and Kelly (2008) proposed a model that focuses on the emotional and personality aspects in the career process. The model, which they describe 
as emotional and personality-related career decision making difficulties (EPCD), consists of three basic categories as pessimistic views, anxiety and self-identity, and 11 sub-categories. EPCD indicate a high level of anxiety, the individual's negative thoughts about both her/himself and the making a decision about career, and a more intense and violent indecisiveness that is characterized by identity disintegration (Saka et al., 2008; Saka \& Gati, 2007). One of the three basic categories is pessimistic views. Pessimistic views comprise of negative beliefs on the world of work, the process and the control of the individual. Anxiety, on the other hand, indicates anxiety about the uncertainty of the future, and the stress experienced by the individual about decision-making. The last category, self-concept and identity, signifies dissatisfaction, feelings of worthlessness and not being supported by important others (Jin, Nam, Joo, \& Yang, 2015; Gati, Asulin-Peretz, \& Fisher, 2012; Saka et al., 2008; Saka \& Gati, 2007).

Sociocultural experiences such as the perception of the society about professions and the social environment of the individual also affect the career decisions of adolescents (Santrock, 2012). In addition, the role of parents in adolescents' profession choices is quite large and this role affects adolescents' choice of profession, sometimes positively and sometimes negatively (Özünlü \& Bacanl, 2015). In summary, people around the individual influence her/his career choice.

Being a social entity, a human communicates and interacts with other individuals around her/him in order to survive. In this sense, social support received from others can be thought as an important part of an individual's life. Social support is defined as information that enables the individual to believe that $\mathrm{s} / \mathrm{he}$ is valued, loved and is a member of a group to which he is mutually responsible (Cobb, 1976). Simply put, social support refers to the care and assistance that a person can benefit from other people (Lam, 2019). Perceived social support is defined as the judgment of the individual regarding whether the level of social support s/he takes is sufficient (Procidano \& Heller, 1983). It is stated that social support is an important concept in solving the problems of the individual regarding future career plans (Patel, Salahuddin, \& O'Brien, 2008). Considering the previous researches, some relations between other aspects of career development, career difficulties and social support were found. For example, Öztemel (2013a) found that as the social support levels of high school student's increase, their career decision-making difficulties decrease. Similarly, Sürücü (2005) found a positive relationship between vocational maturity and perceived social support. In another study (Mert, Duman, \& Kahraman, 2019), it was found that perceived social support predicted self-efficacy of career decision-making. In yet another study, Bacanl1 (2012) states that in the profession choice of individuals who have career decision-making difficulties, factors other than themselves play a role, and these people experience external conflicts arising from individuals around the them such as parents, other relatives, friends and teachers. These results suggest that social support from parents, friends and other important people may be associated with career difficulties. Therefore, it is thought in this research that perceived social support and EPCD may be related.

Considering that vocational guidance practice was initiated in the early twentieth century to address social and psychological needs, one of the factors affecting the individual's career decision-making difficulties may be conceived as psychological needs (Tang, 2003). While meeting the psychological needs affects the individual's career and career choice, the relationship between them has not been fully worked out (Hetland, Hetland, Andreassen, Pallesen, \& Notelaers, 2011). The self-determination theory assumes that the individual has three basic needs: innate autonomy, competence and relatedness (Ryan \& Deci, 2000). Heckert et al. (2000) classified psychological needs as achievement, commitment, autonomy and dominance. It is observed that meeting basic psychological needs is positively associated with some positive dispositional (e.g., satisfaction). Conversely it is negatively associated with anxiety symptoms (Wei, Shaffer, Young, \& Zakalik, 2005).

Research examining the relationship between career difficulties and psychological needs is very limited (Ex: Cordeiro, Paixão, Lens, Lacante, \& Luyckx, 2018; Holding, St-Jacques, Verner-Filion, Kachanoff, \& Koestner, 2019). Kuzgun (2014) states that psychological needs are related to professional activities and that psychological needs are expected to play a role in individuals' choice of profession. It is stated that individuals facing career-related problems tend to see the profession as the most important source of satisfaction. Therefore, it is thought in this study that basic psychological needs may be related to EPCD.

Considering the relevant literature, examining the basic psychological needs of high school students and the level of social support they perceive from others, and their relationship with EPCD are considered important in that they will give some tips on how high school students can make their career plans healthier. It is also seen that there are 5.649.594 high school students, and 12.506 schools in the 2018-2019 academic year (MEB, 2019). Considering the relevant numbers, and that there is a wide population to choose a career, it is important to investigate the career decision of the students. Therefore, determining the relationships between high school students' career difficulties including emotional and personality and other variables can both help students understand the dynamics of the decision process, and help school psychological counselors take positions in career-related issues. In this context, 
the current study aims to examine whether students' basic psychological needs and perceived social support would predict EPCD. In addition, in this study, it is examined whether there is a significant difference between the EPCD of high school students according to gender, grade level and whether they decide on a profession or not.

\section{Method}

\subsection{Research Method}

In this research, survey model, which is one of the quantitative research methods, was used. The survey model is a structured approach for data collection and analysis and is based on certain analysis techniques (De Vaus, 2002).

\subsection{Study Group}

The study group of the study consists of 445 students (114 females, 327 males, and 4 people did not specify their gender) studying in several high schools in Ankara. The ages of the students ranged between 14-18 and the average age was found as $15.65(\mathrm{Sd}=1.12)$. Considering the grade level, $28 \%$ of the students $(\mathrm{n}=123)$ are in the $9^{\text {th }}$ grade, $28 \%(\mathrm{n}=126)$ are in the $10^{\text {th }}$ grade, $23 \%(\mathrm{n}=102)$ are in the $11^{\text {th }}$ grade, and $21 \%(\mathrm{n}=92)$ are in the $12^{\text {th }}$ grade $(2$ students did not specify their grade level). $95 \%$ of the participants reported that they perceived themselves at a middle socio-economic level.

\subsection{Measures}

The Emotional and Personality-Related Career Decision-Making Difficulties Scale-Short Form (EPCD-SF): The Turkish version of the long form of the 53-item scale, developed by Saka, Gati and Kelly (2008), was made by Öztemel (2013b). Later, a short form of the scale was created (Öztemel, 2014a). SF-EPCD, which has a validity and reliability study on 428 students, consists of 25 items ( 1 exercise, 2 validities, 22 difficulties) and 9-point Likert-type grading $(1=$ does not fit me, $9=$ completely fits me). First level and second level confirmatory factor analysis (CFA) were performed for the validity study of EPCD-SF, consisting of three subscales: pessimistic views, anxiety, and self and identity (11 subscales spread within these scales). As a result of the first level CFA, the goodness of fit coefficients was $(\chi 2(206)=765.530, \chi 2 / \mathrm{sd}=3.72, \mathrm{GFI}=.86, \mathrm{NFI}=.90, \mathrm{CFI}=.93$, and RMSEA $=.080$. As a result of the second level CFA, goodness of fit coefficients was calculated as $\chi 2(204)=514.706, \chi 2 / \mathrm{sd}$ $=2.52, \mathrm{GFI}=.90, \mathrm{CFI}=.96, \mathrm{NFI}=.93$, and RMSEA $=.060$. Also, the scale was applied with the Scale of Personal Indecision for criterion validity (Bacanl, 2005), and positive and significant relations were found between two scales. Internal consistency coefficient was calculated for reliability analysis and it was found as $\alpha=.65$ for pessimistic views subscale, $\alpha=.84$ for anxiety subscale and $\alpha=.77$ for self and identity subscale, and $\alpha=.88$ for the whole scale. The test-retest reliability coefficient of the scale was calculated as $\alpha=.70$. For this study, the Cronbach Alpha internal consistency coefficient was $\alpha=.64$ for pessimistic views subscale, $\alpha=.86$ for anxiety subscale, $\alpha=.79$ for self and identity subscale, and $\alpha=.90$ for the whole scale. In this research, the analyses were made for the whole scale. In this study, it was found as $\alpha=88$.

New Psychological Needs Assessment Scale (NPNAS): The New Psychological Needs Assessment Scale (NPNAS) was developed by Heckert et al. (2000). It was adapted to Turkish culture by Kesici (2008). The scale consists of four subscales: achievement, affiliation, autonomy and dominance. It is 5-point Likert type and has 20 items. A positive and significant correlation was found between the original form and the Turkish form of the scale. As a result of CFA, fit indices were found as $\mathrm{x}^{2}=5636,877,(\mathrm{sd}=170, \mathrm{p}<.01),\left(\mathrm{x}^{2} / \mathrm{sd}\right)=3.15$, RMSEA $=.10$, RMS $=.11$, GFI $=.76$ and AGFI $=.70$. Internal consistency coefficients were found as .77 in the achievement sub-dimension, .62 in the affiliation sub-dimension, .72 in the autonomy sub-dimension, .77 in the dominance sub-dimension, and .80 in the whole scale. In this research, it was found that achievement sub-dimension was $\alpha$ $=.65$, affiliation sub-dimension was $\alpha=.31$, autonomy sub-dimension was $\alpha=.47$, and dominance sub-dimension was $\alpha=.74$.

Multidimensional Scale of Perceived Social Support (MSPSS): The scale was developed by Zimet, Dahlem, Zimet, and Farley (1988) in order to measure the social support perceived by individuals. It was adapted by Eker and Arkar (1995) into Turkish. The scale consists of 12 items. There are three sub-dimensions (friends, family and significant others). The MSPSS is also evaluated over the total score. The validity and reliability study of the MSPSS for people of 12-22 years was conducted by Çakır and Palabıyıkoğlu (1997). As a result of the factor analysis made with the Main Components Method and Varimax Rotation, the structure of the scale was found similar to the original. Test-retest reliability was found to $b e r=.81$ for total score, $r=.81$ for friend, $r=.72$ for family, $r=.84$ for the significant other. The reliability coefficient of the scale was calculated as $\alpha=.76$ for the whole scale, $\alpha=.84$ for the family, $\alpha=.83$ for the friend and $\alpha=.82$ for the significant other. The Cronbach's Alpha coefficient of the whole scale was found .89 in this study.

Personal Information Form (PIF): In the PIF created by researchers, there are questions aimed at obtaining 
information about high school students' gender, age, grade, perceived socio-economic level and whether they decide on a profession or not.

\subsection{Data Collection}

The scales used in the research were applied by the researchers after obtaining permission from the Provincial Directorate of National Education. Before the application, the purpose of the research was explained to the students and it was stated that they might not participate if they wanted. The volunteer students were given a scale set and the set was filled under the supervision of teachers and researchers. It was stated that if they want to receive information about themselves individually, they can get information from the e-mail addresses specified in the instructions of the scale set and after the specified period. It took about 30-40 minutes to fill the scale set.

\subsection{Data Analysis}

The data were analyzed using SPSS (20) package program. However, before analyzing the data, 27 data that were determined to be extreme values were excluded from the study sets by looking at Mahalanobis Distance, Cooks, Leverage values. Mahalanobis Distance, Cooks, Leverage values are used to determine extreme data (Kannan \& Manoj, 2015). After the extreme values were excluded, skewness and kurtosis values were examined to determine whether the data are suitable for normal distribution. If the Skewness and Kurtosis coefficients are between -1 and +1 , it can be accepted that the distribution provides normality (Hair, Black, Babin, Anderson \& Tatham, 2006). The skewness and kurtosis coefficients of the data are given in Table 1.

Table 1. Skewness and kurtosis values of variables

\begin{tabular}{lcc}
\hline & Skewness & Kurtosis \\
\hline EPCD-SF & .099 & -.471 \\
Achievement & -.428 & -.286 \\
Affiliation & -.352 & .114 \\
Dominance & -.306 & -.470 \\
Autonomy & -.042 & -.584 \\
Social Support & -.688 & -.166 \\
\hline
\end{tabular}

Note. EPCD-SF = Emotional and Personality-Related Career Decision-Making Difficulties Short Form

As it can be seen in Table 1, the variables in the study are between -1 and +1 . In this regard, it can be said that the data show normal distribution. Parametric analyzes were used because the data showed normal distribution. In the analysis of the data, independent t-test, ANOVA, Pearson correlation coefficient, and multiple linear regression analysis were used.

\section{Results}

Whether there is a difference EPCD according to the gender of high school students in the study group were examined with t-test analysis and the results are given in Table 2.

Table 2. T-test results on comparison of emotional and personality-related career decision-making difficulties scale by gender

\begin{tabular}{ccccccc}
\hline Gender & $\mathrm{n}$ & $\bar{X}$ & $\mathrm{Sd}$ & $\mathrm{t}$ & $\mathrm{p}$ & $\eta^{2}$ \\
\hline Female & 114 & 124.47 & 31.19 & 3.26 & $.001^{*}$ & .02 \\
Male & 327 & 113.82 & 29.58 & & & \\
\hline
\end{tabular}

Note. ${ }^{*} \mathrm{P}<.01$.

As it can be seen in Table 2, the mean score $(\bar{X}=124.47)$ received by female students from SF-EPDC is significantly higher than that of male students $\bar{X}=113.82)(\mathrm{t}(439)=3.26, \mathrm{p}<.01, \eta 2=.02)$. The average and standard deviation values for total scores of EPCD according to grade levels of high school students are given in Table 3 . 
Table 3. Descriptive statistics of the EPCD by grade level

\begin{tabular}{cccc}
\hline Grade & $\mathrm{N}$ & $\bar{X}$ & $\mathrm{Sd}$ \\
\hline 9 & 123 & 116.31 & 30.09 \\
10 & 126 & 110.29 & 28.62 \\
11 & 102 & 117.55 & 29.47 \\
12 & 92 & 124.96 & 32.78 \\
Total & 443 & 116.68 & 30.45 \\
\hline
\end{tabular}

When Table 3 is examined, it is seen that $12^{\text {th }}$ grade students $(\bar{X}=124.96)$ have the highest average score from the EPCD. Then are $11^{\text {th }}$ grade students $(\bar{X}=117.55), 9^{\text {th }}$ grade students $(\bar{X}=116.31)$ and $10^{\text {th }}$ grade students $(\bar{X}=$ 110.29). Whether there is a difference between the averages in terms of grade level was examined with ANOVA test.

Table 4. Group comparisons of the EPCD by grade level

\begin{tabular}{cccccccc}
\hline & Sum of Squares & $\mathrm{Sd}$ & Mean of Squares & $\mathrm{F}$ & $\mathrm{p}$ & $\eta^{2}$ & difference \\
\hline Between groups & 11546.578 & 3 & 3848.859 & & & .03 & $12>9$ \\
Within groups & 398452.322 & 439 & 907.636 & 4.241 & $.006^{*}$ & & $12>10$ \\
Total & 409998.899 & 442 & & & & & \\
\hline
\end{tabular}

Note. $* \mathrm{P}<.05$.

As it can be seen from Table 4., high school students' total scores of the EPCD differ significantly according to grade level $(\mathrm{F}(3.439)=4.241, \mathrm{p}<.05)$. Retracing the difference, it was determined after LSD test that the mean scores that the score $12^{\text {th }}$ grade students received from the scale of career decision-making difficulties $(\bar{X}=$ $124.96)$ were significantly higher $(\mathrm{p}<.05)$ than that of $9^{\text {th }}$ grade $(\bar{X}=116.31)$ and $10^{\text {th }}$ grade $(\bar{X}=110.29)$ students. Whether there is a difference in the EPCD depending on whether high school students decide on a profession or not, are analyzed with t-test and the results are given in Table 5.

Table 5. Group comparison of the EPCD According to the decision status

Note. ${ }^{*} \mathrm{p}<.001$.

\begin{tabular}{ccccccc}
\hline Decision status & $\mathrm{N}$ & $\bar{X}$ & $\mathrm{Sd}$ & $\mathrm{t}$ & $\mathrm{p}$ & $\eta^{2}$ \\
\hline Yes & 344 & 112.07 & 28.41 & -6.545 & $000^{*}$ & .09 \\
No & 97 & 133.81 & 30.55 & & & \\
\hline
\end{tabular}

When Table 5 is examined, the mean scores of the students, who state that they have decided on a profession, from $\operatorname{EPCD}(\bar{X}=112.07)$ are significantly lower than the mean scores of students who have not yet decided on a profession $(\bar{X}=133.81)(\mathrm{t}(439)=-6.545, \mathrm{p}<.001, \eta 2=.09)$. Correlations between the variables are given in Table 6.

Table 6. Correlations between variables

\begin{tabular}{lcccccccc}
\hline Variables & $\bar{X}$ & $\mathrm{Sd}$ & 1 & 2 & 3 & 4 & 5 & 6 \\
\hline 1. EPCD-SF & 116.65 & 30.39 & - & $-.198^{* *}$ & .075 & -.058 & $.106^{*}$ & $-.171^{* *}$ \\
2. Achievement & 20.46 & 2.76 & - & -.059 & $.492^{* *}$ & $.294^{* *}$ & $.279^{* *}$ \\
3. Affiliation & 15.71 & 2.61 & & - & -.063 & -.078 & $.228^{* *}$ \\
4. Dominance & 19.83 & 3.27 & & & - & $.561^{* *}$ & .061 \\
5. Autonomy & 19.36 & 2.62 & & & & - & -.003 \\
6. Social support & 64.75 & 14.16 & & & & & - \\
\hline
\end{tabular}

Note. ${ }^{*} \mathrm{p}<.05, * * \mathrm{p}<.01$.

When Table 6 is examined, it is seen that there are negative and significant relationships between EPCD and the need for achievement and social support $(\mathrm{r}=-.198, \mathrm{r}=-.171, \mathrm{p}<.01$, respectively); and there is a positive and 
significant relationship $(\mathrm{r}=.106, \mathrm{p}<.05)$ between EPCD and the need for autonomy. On the other hand, it is understood that there is no significant relationship between EPCD and affiliation need and dominance need ( $\mathrm{r}$ $=.075, \mathrm{r}=-.058, \mathrm{p}>.05$, respectively). Whether achievement, autonomy and perceived social support, which are among the basic psychological needs, predicted EPCD together was examined by multiple linear regression analysis.

Table 7. Regression analysis results regarding prediction of emotional and personality-related career decision-making difficulties

\begin{tabular}{ccccc}
\hline Variables & $\mathrm{B}$ & $\mathrm{SE}$ & $\beta$ & $\mathrm{t}$ \\
\hline Constant & 142.832 & 13.535 & & 10.553 \\
Achievement & -2.389 & .549 & -.218 & $-4.353^{* *}$ \\
Autonomy & 1.960 & .555 & .170 & $3.533^{* *}$ \\
Social support & -.235 & .103 & -.110 & $-2.294^{*}$ \\
\hline
\end{tabular}

Note. $\mathrm{R}=.28, \mathrm{R}^{2}=.08, \mathrm{~F}_{(3-441)}=12.753, \mathrm{p}<.001, * \mathrm{p}<.05, * * \mathrm{p}<.001$, Durbin Watson $=1.819$.

When Table 7 is examined, Regression Analysis results regarding Career Decision-Making Difficulties Scale are seen. When Table 7 is examined, it is seen that all variables specified as the predictor variable significantly predict the $\operatorname{EPCD}\left(\mathrm{R}=.28, \mathrm{R}^{2}=.08, \mathrm{~F}=12.753, \mathrm{p}<.001\right)$, and it explains approximately $8 \%$ of the Total Variance related to the Career Decision-Making Difficulties Scale. When the relevant $\beta$ values are examined, it is seen that the strongest predictor variable is the Achievement Scale $(\beta=-.218)$, which is one of sub-dimensions of the Basic Psychological Needs Scale. This is followed by the Autonomy Scale $(\beta=.170)$ and Perceived Social Support Scale $(\beta=-.110)$, which are sub-dimensions of Basic Psychological Needs Scale, respectively.

\section{Discussion}

The main purpose of the current research is to examine whether the basic psychological needs and perceived social support levels of high school students predict career difficulties. In addition, it was investigated whether the EPCD of high school students differed in terms of gender, grade level and status of making a decision on a profession.

According to the findings obtained in the study, difficulties of female students were found higher than that of male students. When the literature is examined, it is seen that there are studies supporting this finding. For example, Öztemel (2014b) found that difficulties of female students were higher than that of male students in his research on high school students. Similarly, Gati et al. (2011) found that the difficulties of female students are higher than that of male students in their research on university students' sample. Similarly, some other studies (e.g. Bacanl1, 2012; Öztemel, 2013a) found significant differences in terms of gender and career difficulties. While the general principles of emotional function that apply to career decision-making apply to most situations, the specific relationship between emotions and career decisions may differ by gender (Jiang, 2014). This situation may be due to the fact that males tend to avoid responsibility in terms of gender roles, females have a more sensitive, thoughtful and responsible nature than males, and accordingly females display a more general indecisiveness compared to males (Öztemel, 2014b; Gülbahçe \& Kartol, 2014). In return, there are some non-consistent results. For example, Öztemel (2013b) and Shin and Kelly (2015) did not encounter gender differences in difficulties. Obiunu (2008) found that gender did not affect the career decision-making process.

In this study, it was found that the students, who decided on a profession, got significantly lower scores on the EPCD than that of the students who did not decide on. In the study conducted by Dursun and Kara (2019), it was found that the expectation of career decision competence significantly predicted career decision-making difficulties. Bacanlı, Eşici, and Özünlü (2013) reached a similar result. This is an expected finding. Students who choose their future profession are expected to experience less difficulty in deciding on their careers.

In this study, it was found that 12th grade students' mean scores on the EPCD were significantly higher than the average scores of 9 th grade and 10th grade students. Although individuals in the high school period are less idealistic in the first years, it is getting more important for them to decide about their careers and discover different career opportunities as they age (Santrock, 2012). The reason for this situation may be that graduation of 12th grade students is imminent, they will take the Higher Education Institutions Exam and they will have a more limited time than 9th and 10th grade students to choose a profession since they will make a choice according to their scores at the end of the exam.

In this study, a negative correlation was found between the mean scores of high school students on the EPCD and 
the mean score on Achievement Scale, which is a sub-dimension of the Psychological Needs Scale. In addition, the Achievement Sub-Dimension is a significant predictor of the EPCD. Achievement need is considered to be one of the basic human needs to achieve goals that affect the behavior and thoughts of the individual (Gerrig \& Zimbardo, 2014). Individuals, who need more achievement, tend to jobs and professions that they will be responsible for the results (Burger, 2006). In this context, students with a high need for achievement may have less career decision-making difficulties, both because they see profession choice as a task and have desire to fulfill it, and they want to decide on the profession in advance, which they think they will be successful in. In his study, Bacanli (2012) found that students, who perceive their academic achievement as poor, have more career decision-making difficulties than students, who perceive them as good. The literature is compatible with the study.

In this study, the correlation was not found between the mean scores of students on the EPCD Scale and the affiliation. Affiliation refers to the experience of healthy social connectivity and satisfying social relationships. Individuals should feel that they have significant interactions with significant others (Faye \& Sharpe, 2008). The affiliation need sub-scale may not be a factor affecting the individual's career decision since it represents the relationship that is needed, not the relationships that the individual has.

In this study, the correlation was not found between the mean scores of students on the EPCD Scale and the mean scores on dominance sub-scale. Dominance is important during adolescence (van Veen, 2019). People in need of dominance may want to dominate, influence others and positively position themselves in relationships (Burgoon \& Dunbar, 2000). In the literature, there is a significant positive relationship between career need and dominance (Folberg \& Ryan, 2019). It is thought that students with higher dominance needs will choose their profession according to this need and will experience less career indecisiveness. In this regard, this finding is remarkable.

In this study, the correlation was not found between the mean scores of students on the EPCD Scale and the mean scores on autonomy scale, which is one of the sub-dimensions of Psychological Needs Scale. In addition, the Autonomy Sub-Dimension is a significant predictor of the EPCD Scale. The reason for the need of autonomy of individuals can be stated in two main categories as: 1 . effort to avoid pressure and optional choice, 2. efforts to create and realize original and guiding values, goals and interests (Assor, 2012). The need for autonomy means that individuals try to make choices in initiating, maintaining and regulating their behavior (Guay, Senécal, Gauthier, \& Fernet, 2003). In addition, the autonomy degree of the decision and autonomy support are thought to lead to positive cognitive and emotional outcomes (Katz, Cohen, Green-Cohen, \& Morsiano-Davidpur, 2018). In this context, as the need for autonomy increases, students may experience career indecisiveness because they think of many professions and find it difficult to find the profession they want to practice independently.

In this study, a significant negative correlation was found between the average scores of high school students on EPCD Scale and the average scores on Perceived Social Support Scale. In addition, Perceived Social Support Perception Scale is a significant predictor of the Career Decision-Making Scale. Li (2014) found that social support reduced the impact of career decision-making difficulties. In the study conducted by Sahin and Kurdök (2018), it was determined that social support by family, friend and teacher increased the career adaptation of high school students. Bright, Pryor, Wilkenfeld, and Earl (2005) stated that social context was effective on students' career decisions. These findings are in line with the study. Öztemel (2013a), on the other hand, found a significant negative relationship between career decision-making difficulties and perceived teacher social support, while no significant relationship was found with perceived family and friend social support. Social support can influence people's perspective on the world, society and other people. With the effect of this; in new situations and incidents, functions of thinking, evaluating and decision-making may be affected by the perception of social support (Dülger, 2009).

In this study, the relationship between emotional and personality-related career decision-making difficulties, perception of social support and basic psychological needs of high school students was examined. Due to the fact that current researches in the sample of Turkey focus on more cognitive abilities in career decision-making process of individuals, it is thought that emotional traits are neglected. For this reason, it is thought that this study will contribute to the study of the emotional characteristics and psychological needs of the students.

\section{Recommendations}

In this study, a significant negative correlation was found between the average scores of students on EPCD Scale and the average scores on Perceived Social Support Scale. People are a social species and may need to trust others while doing something. Social behavior is embedded in both biological and cultural systems (Lam, 2019). For these reasons, doing activities for high school students to develop social support resources may enable them to have less career decision-making difficulties. In addition, the analysis of social support networks can shed light on the academic achievement of young people, major developments in educational pathways or an increased 
probability of academic continuity (Esteban, Martí, \& Hila, 2016). In future researches, experimental studies on the effect of social support on career decision-making difficulties and skills can be conducted.

In this study, EPCD of high school students were examined according to gender and class demographic variables. In later studies, disadvantaged students in the decision-making process can be identified by determining whether the EPCD differ with wider demographic information.

In this study, a negative correlation was found between the average scores of high school students on the EPCD Scale and the average scores on the Achievement Scale, which is one of the Psychological Needs Scale sub-dimensions. Implicitly or explicitly, it is assumed that individuals intentionally choose their career path while striving for psychological success (Forrier, Sels, \& Verbruggen, 2005). Achievement needs can be used in guidance services as a motivating factor for students with career indecisiveness.

\section{References}

Assor, A. (2012). Allowing choice and nurturing an inner compass: Educational practices supporting students' need for autonomy. In Handbook of research on student engagement (pp. 421-439). Springer, Boston, MA. https://doi.org/10.1007/978-1-4614-2018-7_20

Bacanlı, F. (2000). Kararsızlık Ölçeğinin Geliştirilmesi. Türk Psikolojik Danışma ve Rehberlik Dergisi, 2(14), $7-16$.

Bacanlı, F. (2012). Kariyer karar verme güçlükleri ve meslek seçimine ilişkin akılcı olmayan inançların ilişkisi. Türk Psikolojik Danışma ve Rehberlik Dergisi, 4(37), 86-95.

Bacanlı, F. (2016). Kariyer karar verme güçlükleri ve meslek seçimine ilişkin akılcı olmayan inançların ilişkisi. Türk Psikolojik Danışma ve Rehberlik Dergisi, 4(37).

Bacanlı, F., Eşici, H., \& Özünlü, M. B. (2013). Kariyer karar verme güçlüklerinin çeşitli değişkenlere göre incelenmesi. Türk Psikolojik Danışma ve Rehberlik Dergisi, 4(40), 198-211.

Bright, J. E., Pryor, R. G., Wilkenfeld, S., \& Earl, J. (2005). The role of social context and serendipitous events in career decision making. International journal for educational and vocational guidance, 5(1), 19-36. https://doi.org/10.1007/s10775-005-2123-6

Burger, J. M. (2006). Kişilik (çev. Deniz E. Sarığlu). İstanbul: Kaktüs Yayınları.

Burgoon, J. K., \& Dunbar, N. E. (2000). An interactionist perspective on dominance-submission: Interpersonal dominance as a dynamic, situationally contingent social skill. Communications Monographs, 67(1), 96-121. https://doi.org/10.1080/03637750009376497

Çakır, Y., \& Palabıyıkoğlu, R. (1997). Gençlerde sosyal destek-çok boyutlu algılanan sosyal destek ölçeğinin güvenirlik ve geçerlik çalışması. Kriz Dergisi, 5(1), 15-24. https://doi.org/10.1501/0000861

Cobb, S. (1976). Social support as a moderator of life stress. Psychosomatic medicine, 38(5), 300-314. https://doi.org/10.1097/00006842-197609000-00003

Cordeiro, P. M. G., Paixão, M. P., Lens, W., Lacante, M., \& Luyckx, K. (2018). Parenting styles, identity development, and adjustment in career transitions: The mediating role of psychological needs. Journal of Career Development, 45(1), 83-97. https://doi.org/10.1177/0894845316672742

Davidson, S. L., \& Gilbert, L. A. (1993). Career counseling is a personal matter. The career development quarterly, 42(2), 149-153. https://doi.org/10.1002/j.2161-0045.1993.tb00428.x

De Vaus, D. A. (2002). Surveys in social research. Allen \& Unwin. https://doi.org/10.4135/9781446263495

Dülger, Ö. (2009). Ergenlerde algılanan sosyal destek ile karar verme davranışları arasındaki ilişkinin incelenmesi (Yayınlanmamış yüksek lisans tezi). Marmara Üniversitesi Eğitim Bilimleri Enstitüsü, İstanbul.

Dursun, A., \& Kara, A. (2019). Ortaöğretim Öğrencilerinde Kariyer Karar Verme Güçlüklerinin Yordayıcısı Olarak Kariyer Kararı Yetkinlik Beklentisi ve Kariyer Seçiminde Aile Etkisi. Journal of Turkish Educational Sciences, 17(1).

Eker, D., \& Arkar, H. (1995). Çok Boyutlu Algılanan Sosyal Destek Ölçeğinin Faktör Yapısı, Geçerlik ve Güveniriliği. Türk Psikoloji Dergisi, 101(34), 45-55.

Esteban, M. P. S., Martí, A. S., \& Hila, A. B. C. (2016). Measuring Social Capital and Support Networks of Young Immigrants. International Education Studies, 9(5), 62-74. https://doi.org/10.5539/ies.v9n5p62

Faye, C., \& Sharpe, D. (2008). Academic motivation in university: The role of basic psychological needs and 
identity formation. Canadian Journal of Behavioural Science/Revue canadienne des sciences du comportement, 40(4), https://doi.org/10.1037/a0012858

Folberg, A. M., Kercher, K., \& Ryan, C. S. (2019). The Hidden Role of Dominance in Career Interests: A Bifactor Analysis of Agentic and Communal Goal Orientations. Sex Roles, 1-18. https://doi.org/10.1007/s11199-019-01104-1

Forrier, A., Sels, L., \& Verbruggen, M. (2005). Career Counseling in the New Career Era: A Study about the Influence of Career Types, Career Satisfaction and Career Management on the Need for Career Counseling. SSRN Journal, 1, 37. https://doi.org/10.2139/ssrn.878279

Gaff, I., Krausz, M., \& Osipow, S. H. (2000). A taxonomy of difficulties in career decision making. Journal of Counseling Psychology, 43(4), 510-526. https://doi.org/10.1037/0022-0167.43.4.510

Gati, I., \& Tal, S (2018). Decision-making models and career guidance. In J. Athanasou, \& R. Van Esbroeck (Eds.), International handbook of career guidance. Berlin, Germany: Springer. https://doi.org/10.1007/978-3-030-25153-6_6

Gati, I., Asulin-Peretz, L., \& Fisher, A. (2012). Emotional and personality-related career decision-making difficulties: A 3-year follow-up. Counseling Psychologist, 40(1), 6-27. https://doi.org/10.1177/0011000011398726

Gati, I., Gadassi, R., Saka, N., Hadadi, Y., Ansenberg, N., Friedmann, R., \& Asulin-Peretz, L. (2011). Emotional and personality-related aspects of career decision-making difficulties: Facets of career indecisiveness. Journal of Career Assessment, 19, 3-20. https://doi.org/10.1177/1069072710382525

Gerrig, R. J., \& Zimbardo, P. G. (2014). Psikolojiye Giriş Psikoloji ve Yaşam (Çev. Gamze Sart). Ankara: Nobel Yayınları.

Gökçe, Z., \& Traş, Z. (2017). Lise öğrencilerinin kariyer karar verme güçlükleri ve ego kimlik statülerinin bazı değişkenlere göre incelenmesi. Türk Eğitim Bilimleri Dergisi, 15(1), 58-69.

Guay, F., Senécal, C., Gauthier, L., \& Fernet, C. (2003). Predicting career indecision: A self-determination theory perspective. Journal of counseling psychology, 50(2), 165. https://doi.org/10.1037/0022-0167.50.2.165

Gülbahçe, A., \& Kartol, A. (2014). İlköğretim Sekizinci Sınıf Öğrencilerinin Karar Verme Stratejilerinin Bazı Değişkenler Açısından İncelenmesi. Bayburt Eğitim Fakültesi Dergisi, 9(2), 132-143.

Hair, J. F., Black, W. C., Babin, B. J., Anderson, R. E., \& Tatham, R. L. (2006). Multivariate data analysis (pp. 69-72). New Jersey: Hoboken.

Heckert, T. M., Cuneio, G., Hannah, A. P., Adams, P. J., Droste, H. E., Mueller, M. A., ... \& Roberts, L. L. (2000). Creation of a new needs assessment questionnaire. Journal of Social Behavior and Personality, 15(1), 121-136. https://doi.org/10.1037/e413782005-409

Hetland, H., Hetland, J., Andreassen, C. S., Pallesen, S., \& Notelaers, G. (2011). Leadership and fulfillment of the three basic psychological needs at work. Career Development International, 16(5), 507-523. https://doi.org/10.1108/13620431111168903

Holding, A. C., St-Jacques, A., Verner-Filion, J., Kachanoff, F., \& Koestner, R. (2019). Sacrifice—but at what price? A longitudinal study of young adults' sacrifice of basic psychological needs in pursuit of career goals. Motivation and Emotion, 1-17. https://doi.org/10.1007/s11031-019-09777-7

Jiang, Z. (2014). Emotional intelligence and career decision-making self-efficacy: National and gender $\begin{array}{llll}\text { differences. Journal of employment counseling, } & 51(3), & 112-124 .\end{array}$ https://doi.org/10.1002/j.2161-1920.2014.00046.x

Jin, L., Nam, S. K., Joo, G., \& Yang, E. (2015). Validation of a Korean translation of the emotional and personality-related career decision-making difficulties scale-short form (EPCD-SF). Journal of Career Assessment, 23(2), 294-307. https://doi.org/10.1177/1069072714535173

Kannan, K. S., \& Manoj, K. (2015). Outlier detection in multivariate data. Applied Mathematical Sciences, 47, 2317-2324. https://doi.org/10.12988/ams.2015.53213

Katz, I., Cohen, R., Green-Cohen, M., \& Morsiano-Davidpur, S. (2018). Parental support for adolescents' autonomy while making a first career decision. Learning and Individual Differences, 65, 12-19. https://doi.org/10.1016/j.lindif.2018.05.006

Kesici, Ş. (2008). Yeni Psikolojik İhtiyaç Değerlendirme Ölçeğinin Türkçe Formunun Geçerlik Ve Güvenirlik 
Çalışması: Doğrulayıcı Faktör Analizi Sonuçları. Selçuk Üniversitesi Sosyal Bilimler Enstitüsü Dergisi, 20, 493-500.

Kirdök, O. (2018). Secondary School Students' Positive and Negative Perfectionism as a Predictor of Career Development. Educational Research and Reviews, 13(20), 696-703. https://doi.org/10.5897/ERR2018.3594

Kuzgun, Y. (2009). Meslek Rehberliği ve kariyer danışmanlığına giriş. Ankara: Nobel Kitapevi.

Kuzgun, Y. (2014 ). Meslek gelişimi ve danışmanlığı. Ankara: Nobel Yayınevi.

Lam, B. H. (2019). Social support, well-being, and teacher development. Singapore: Springer. https://doi.org/10.1007/978-981-13-3577-8

Lent, R. W., \& Brown, S. D. (2013). Understanding and facilitating career development in the 21 st century. In S. D. Brown, \& R. W. Lent (Eds.), Career development and counseling: Putting theory and research to work (pp. 1-26). Hoboken, NJ: Wiley \& Sons.

Li, Y. I. (2014). The Impact of Social Support on Career Decision-making: The Role of Relational Self-concept (Unpublished doctoral thesis). The Pennsylvania State University, The Graduate School College of Education Pennsylvania.

MEB. (2019). National Education Statistics Formal Education 2018/19. Ankara, Turkey: Ministry o National Education Strategy Development Presidency. Retrieved from http://sgb.meb.gov.tr/www/icerik_goruntule.php?KNO=361

Mert, A., Duman, A. E., \& Kahraman, M. (2019). Ortaöğretim öğrencilerinde kariyer karar verme öz-yeterliğinin yordayıcıları olarak benlik saygısı ve algılanan sosyal destek. YYÜ Eğitim Fakültesi Dergisi, 16(1), 594-619. https://doi.org/10.23891/efdyyu.2019.183

Obiunu, J. J. (2008). The effects of reciprocal peer tutoring on the enhancement of career decision making process among secondary school adolescents. Educational Research and Reviews, 3(7), 236-241.

Öztemel, K. (2013a). Lise Öğrencilerinin Kariyer Karar Verme Güçlüklerinin Yordayıcıları Olarak Algılanan Sosyal Destek ve Cinsiyet. Türk Ĕ̈itim Bilimleri Dergisi, 11(3), 241-257.

Öztemel, K. (2013b). Testing the validity of the emotional and personality-related career decision-making difficulties questionnaire in Turkish culture. Journal of Career Development, 40(5), 390-407. https://doi.org/10.1177/0894845312468060

Öztemel, K. (2014a). Duygusal ve kişilik ilişkili kariyer karar verme güçlükleri ölçeği’nin kısa formu. Türk Psikolojik Danışma ve Rehberlik Dergisi, 5(42).

Öztemel, K. (2014b). Career indecisiveness of Turkish high school students: Associations with personality characteristics. Journal of Career Assessment, 22(4), 666-681. https://doi.org/10.1177/1069072713515630

Özünlü, M. B., \& Bacanlı, F. (2015). Kariyer Seçiminde Aile Etkisi Ölçeği’nin Lise Öğrencileri İçin Türkçeye Uyarlanması: Geçerlik Ve Güvenirlik Çalışmaları. Türk Eğitim Bilimleri Dergisi, 13(1), 13-32.

Patel, S. G., Salahuddin, N. M., \& O’Brien, K. M. (2008). Career decision-making self-efficacy of Vietnamese adolescents: The role of acculturation, social support, socioeconomic status, and racism. Journal of Career Development, 34(3), 218-240. https://doi.org/10.1177/0894845307308488

Procidano, M. E., \& Heller, K. (1983). Measures of perceived social support from friends and from family: Three validation studies. American journal of community psychology, 11(1), 1-24. https://doi.org/10.1007/BF00898416

Ryan, R. M., \& Deci, E. L. (2000). Self-determination theory and the facilitation of intrinsic motivation, social development, and well-being. American Psychologist, 55(1), 68. https://doi.org/10.1037/0003-066X.55.1.68

Sahin, I., \& Kirdök, O. (2018). Investigation of Relationship between High School Students' Career Adaptability, Subjective Well-Being and Perceived Social Support. International Education Studies, 11(8), 127-135. https://doi.org/10.5539/ies.v11n8p127

Saka, N., \& Gati, I. (2007). Emotional and personality-related aspects of persistent career decision-making difficulties. Journal of vocational behavior, 71(3), 340-358. https://doi.org/10.1016/j.jvb.2007.08.003

Saka, N., Gati, I., \& Kelly, K. R. (2008). Emotional and personality-related aspects of career decision-making difficulties. Journal of Career Assessment, 16, 403-424. https://doi.org/10.1177/1069072708318900

Santrock, J. W. (2012). Ergenlik (Çev. ed. Diğem Müge Siyez). Ankara: Nobel Yayın. 
Shin, Y. J., \& Kelly, K. R. (2015). Resilience and decision-making strategies as predictors of career decision difficulties. The Career Development Quarterly, 63(4), 291-305. https://doi.org/10.1002/cdq.12029

Sürücü, M. (2005). Lise ögrencilerinin mesleki olgunlukları ve algıladıkları sosyal destekleri arasındaki ilişkilerin incelenmesi (Yayınlanmamış yüksek lisans tezi). Gazi Üniversitesi, Eğitim Bilimleri Enstitüsü, Ankara.

Tang, M. (2003). Career counseling in the future: Constructing, collaborating, advocating. The Career Development Quarterly, 52(1), 61-69. https://doi.org/10.1002/j.2161-0045.2003.tb00628.x

Van Veen, J. M. H. (2019). Development of Coercion and Prosociality and its Linkage to Resource Control in Early Adolescence: A Person-Centred Approach using a Short-Longitudinal design (Unpublished master's thesis). Utrecht University, Faculty of Social and Behavioural Sciences, Utrecht.

Wei, M., Shaffer, P. A., Young, S. K., \& Zakalik, R. A. (2005). Adult attachment, shame, depression, and loneliness: The mediation role of basic psychological needs satisfaction. Journal of counseling psychology, 52(4), 591. https://doi.org/10.1037/0022-0167.52.4.591

Zimet, G., Dahlem, N., Zimet, S., \&Farley, G. (1988). The Multidimensional Sale of Perceived Social Support. Journal of Personality Assessment, 52(1), 30-41. https://doi.org/10.1207/s15327752jpa5201_2

\section{Copyrights}

Copyright for this article is retained by the author(s), with first publication rights granted to the journal.

This is an open-access article distributed under the terms and conditions of the Creative Commons Attribution license (http://creativecommons.org/licenses/by/4.0/). 